\title{
Conflicts between Lesser Kestrel Conservation and European Agricultural Policies as Identified by Habitat Use Analyses
}

\author{
JOSÉ L. TELLA, ${ }^{\dagger}$ MANUELA G. FORERO, FERNANDO HIRALDO, \\ AND JOSÉ A. DONÁZAR
}

Estación Biológica de Doñana, C.S.I.C. Avda M ${ }^{a}$ Luisa s.n., 41013 Sevilla, Spain

\begin{abstract}
European pseudo-steppes have suffered from extensive changes in agricultural practices during the past decades with the disappearance of field margins and fallow systems and the increase of biocide treatments. The negative effect on wildlife has led to the adoption by the European Union of policies more compatible with environmental conservation, but decisions about optimal land use are difficult to make because of lack of information. We studied habitat use by the Lesser Kestrel (Falco naumanni), a globally vulnerable species, in a Spanish pseudo-steppe (Los Monegros) where traditional agro-grazing systems are still being practiced, and we compared the results with those of another Spanish pseudo-steppe where modern and intensive agriculture has been implemented. We focused on the use by Lesser Kestrels of habitats subject to changes provoked by recent agricultural policies. Habitat availability was determined in a 3-km radius around 11 colonies, where 23 Lesser Kestrels were radio-tracked during the chick-rearing stage. Habitat selection was determined through compositional analysis. The rank of selected habitats was similar for all kestrels, considering both habitats surveyed and habitats where kestrels bunted. Kestrels selected field margins and cereal fields and rejected abandoned crops and scrubland. This selectivity seemed to be due to prey availability. In the intensively cultivated areas the kestrels selected similar habitats but used only small foraging patches and obtained smaller prey than in the traditional agro-grazing systems, probably because of the irregular distribution of prey resources as a result of the intensive biocide treatments. Consequently, in intensively cultivated habitats Lesser Kestrels had larger bome ranges $\left(63.65 \mathrm{~km}^{2}\right)$ than in those with traditional systems (12.36 $\mathrm{km}^{2}$ ). These differences are reflected in the productivity and population trends of both populations. Thus, the best strategy for conserving the Lesser Kestrel seems to be the maintainance of traditional cereal cultures with low biocide treatments and numerous field margins. Both agricultural intensification and marginal land abandonment (with subsequent scrubland invasion) bave detrimental consequences for this and probably for other pseudo-steppe species. Positive management steps can be encouraged by recent agro-environmental regulations such as the 2078/92 European Union Reglament, which favors the creation of programs in which agricultural practices accord with wildlife conservation.
\end{abstract}

Conflictos Entre la Conservación del Cernícalo Priniilla y la Politica Agraria Comunitaria Determinados por Estudios Sobre Uso del Hábitat

Resumen: Durante las últimas décadas, las prácticas agrícolas en las pseudo-estepas europeas han sufrido fuertes cambios; los márgenes entre campos y los sistemas de barbechado ban tendido a desaparecer mientras se incrementaba el uso de biocidas. Estas tendencias se aceleraron con la puesta en marcha de la Política Agraria Comúniteria (PAC) de la Unión Europea (UE). Sus efectos negativos sobre la vida silvestre ban determinado que la UE adoptara políticas más compatibles con la conservación del medio, pero las decisiones

*email Tella@cica.es

†Current address: Department of Biology, University of Saskatchewan, Saskatoon, Saskatchewan, S7N OW0, Canada, email Tella@duke. usask.ca

Paper submitted August 20, 1996; revised manuscript accepted September 23, 1997. 
acerca del uso óptimo del suelo son difícles de tomar debido a la carencia de información. Nosotros hemos estudiado el uso del hábitat por el cernícalo primilla, una especie amenazada a nivel mundial, en una pseudo-estepa española (Los Monegros) donde se mantienen sistemas tradicionales agro-pastorales; los resultados se comparan con los obtenidos en otra pseudo-estepa española altamente transformada. Nos centramos en el uso de bábitats sujetos a cambios determinados por políticas agrarias recientes. La disponibilidad de hábitat se midió en torno a 11 colonias de cernícalo primilla, donde se siguieron mediante radiotelemetría 23 adultos durante la crianza de pollos, y su selección se determinó mediante el análisis composicional. El rango de los hábitats seleccionados fue similar en todos los individuos, tanto considerando la selección a nivel de hábitats prospectados como de hábitats donde obtuvieron presas. Los cernícalos seleccionaron márgenes de campos y cereales y evitaron campos abandonados y matorral; ello parece ser debido a diferentes rendimientos (disponibilidad de presas). En pseudo-estepas transformadas en áreas de cultivo intensivo los cernícalos seleccionaron hábitats similares pero sólamente usaban pequeñas parcelas para cazar, obteniendo presas de menor tamaño que en pseudo-estepas no alteradas; ello probablemente es debido a la irregular distribución de los recursos como consecuencia de los tratamientos con biocidas. Consecuentemente, en pseudo-estepas transformadas, los cernícalos primillas necesitaron áreas de campeo mayores $\left(63,65 \mathrm{~km}^{2}\right)$ que en aquellas con cultivos tradicionales $\left(12,36 \mathrm{~km}^{2}\right)$. Estas diferencias se reflejaron en la productividad y tendencias de ambas poblaciones. La mejor estrategia para conservar el cernícalo primilla parece ser el mantenimiento de los cultivos cerealistas tradicionales con bajos tratamientos y la potenciación de los márgenes entre campos. La intensificación de la agricultura y el abandono de tierras (con la subsecuente invasión de matorral) son negativos para ésta y probablemente para otras especies esteparias. Las medidas de manejo pueden incentivarse a través de las recientes regulaciones como el Reglamento 2078/92 de la UE que favorece prácticas agricolas respetuosas con la conservación de la fauna silvestre.

\section{Introduction}

Pristine ecosystems in Europe were affected very early in the development of agro-grazing activities and increasing human population density (Wilcove et al. 1986); at present $60 \%$ of the land is covered by agricultural fields (Pain \& Dixon 1997). Human-induced transformations, such as forest destruction and plowing and grazing of the plains of southern Europe, have produced a type of dry grassland called pseudo-steppes, ecosystems with scant trees, flat relief, and an average annual rainfall below $700 \mathrm{~mm}$ (van Dijk 1991). In these areas extensive cultivation of cereal crops is the main land use; the harvested fields remain uncultivated for one or more years (short-medium fallows) and are grazed extensively by livestock herds (Suárez et al. 1997).

During the past few decades the European pseudosteppes have suffered under agricultural practices that have produced important landscape transformations, but the advent of the Common Agricultural Policy of the European Union has accelerated the degradation (Donázar et al. 1997; Potter 1997; Suárez et al. 1997). The relative percentages of crops grown have changed considerably: dry pulse crops, still important in the 1960s, have largely been replaced by cereals and oil-seed crops; the reductions varied between $52 \%$ and $65 \%$ in some Spanish regions. Fallow land has also been affected greatly: in some areas it was reduced from $37 \%$ of the land in $\mathbf{1 9 7 5}$ to $15 \%$ in 1992 . Simultaneously, intensification of cultivation has led to irrigated areas increasing by $77 \%$ since 1960 (Suárez et al. 1997). The use of biocides and fertilizers rose sharply; thus, the inorganic fertilizer application rate was virtually zero in 1950 and rose to $75 \mathrm{~kg}$ of nitrogen per hectare (Ministerio de Agricultura, Pesca y Alimentación 1994). Moreover, the mechanization of agricultural exploitation determined the amalgamation of small landholdings and brought on a twofold increase in the average plot size between 1962 and 1989 (Barceló et al. 1995). In Aragón (our study area), plots of less than 1 ha almost completely disappeared between the $1950 \mathrm{~s}$ and 1982, whereas plots of more than 10 ha that represented only $2 \%$ of the land in 1953 occupied $45 \%$ in 1982 (Nadal et al. 1996). Consequently, field margins have been greatly reduced. In the same area the use of xenobiotic compounds increased 3.6 times between 1975 and 1983 (Nadal et al. 1996). In addition, many marginally cultivated areas have been abandoned, being progressively colonized by natural vegetation (mainly mediterranean scrubland).

There has been a marked decline in the wildlife richness of European dry lowlands coinciding with agricultural expansion (Goriup \& Batten 1990) and in some cases with marginal land abandonment (Rodríguez \& De Juana 1991). Eighty-one percent of the avian species breeding in the pseudo-steppes of southern Europe are classified as Species of European Conservation Concern; $76 \%$ of them have shown recent population declines (Suárez et al. 1997). The most important populations of many of these species remain in the Iberian Peninsula (see reviews in Tucker 1991; Tucker \& Heath 1994).

The negative effects of the environmental components of the Common Agricultural Policy and the problems associated with surplus production and commercialization of products led to reforms during the late 1980s. More substantial reforms were introduced in 1992, including those combining afforestation in unpro- 
ductive farmed lands and intensive cultivation of the rest (Robson 1997). Today, the options are either to abandon marginal cultures, intensively cultivating the rest by means of irrigation, or maintain traditional agro-grazing systems over large areas (Bignal \& McCracken 1996; Suárez et al. 1997). Compatibility between agriculture and environmental conservation is, in general, difficult to determine due to lack of information (Fuller et al. 1995); this is especially true for the pseudo-steppes of southern Europe (Baldock \& Long 1987).

Our main objective was to determine if, as far as the endangered pseudo-steppe wildlife is concerned, it is better to abandon marginal lands and intensify agricultural uses in the most productive zones or to maintain extensive practices over large areas. We used the Lesser Kestrel (Falco naumanni) as a target species in the study. Raptors have been considered sensitive to humaninduced environmental transformations (Newton 1979). Thus, species inhabiting temperate North American agricultural lanscapes have suffered greatly from modern improvements in agro-pastoralism (Colvin 1985; Schmutz 1989; Erichsen et al. 1996; Smallwood et al. 1996). Precise information is lacking, however, about the influence of these changes on European dryland raptors (Donázar et al. 1997). The Lesser Kestrel is a small, migratory falcon; it was once one of the most abundant birds of prey on the continent. During the past decades, however, it has become rare in most of its European area of distribution (Biber 1994). In Spain its population dropped from around 100,000 pairs in the 1960s to only 5000 in 1989 (González \& Merino 1990). Today the species is classified as globally threatened and vulnerable (Collar et al. 1994). The main factor implied in this phenomenon in Spain and other mediterranean countries is the recent changes in agricultural practices (for a review of analyses of potential limiting factors see Negro et al. 1993a; Donázar et al. 1993; Parr et al. 1995; Forero et al. 1996; Bustamante 1997). So far, however, no studies have dealt with the assessment of the future effects of European agricultural policies on this and other threatened steppary species, and no conservation measures to attenuate these potentially negative effects have been considered.

We try to determine the patterns of land use by radiotagged Lesser Kestrel in a pseudo-steppe area of northern Spain where traditional agro-grazing systems are still present. We focus on the use of patchy areas and habitats subject to changes provoked by recent agricultural policies: extensive cereal crops, field margins, abandoned fields, and areas with regenerating scrubland. We also draw a comparison between the results of this study and those obtained by Donázar et al. (1993) in an area of southern Spain where the pseudo-steppe with traditional agro-grazing uses has been replaced by intensive agricultural practices. We try to determine if these transformations have affected the patterns of habitat selection and hunting yield or the home-range sizes of the
Lesser Kestrels. From foraging theory strategy (Stephens \& Krebs 1986) it can be predicted that if agricultural intensification causes impoverishment and/or loss of preferred hunting habitats, Lesser Kestrels exploiting modern agricultural zones would obtain globally lesser hunting yields and exploit larger home ranges than those individuals living in traditional agricultural areas.

\section{Methods}

\section{Study Area}

The endorreic area of Los Monegros $\left(41^{\circ} 20^{\prime} \mathrm{N}, 0^{\circ} 11^{\prime} \mathrm{W}\right.$; Ebro Valley of northeastern Spain) is a plain of approximately $250 \mathrm{~km}^{2}$, between 300 and 360 miles above sea level, consisting of limestone and gypsum soils and several saline lakes that are temporarily flooded. The climate is mediterranean continental semiarid, with $350 \mathrm{~mm}$ of rainfall concentrated in spring and autumn, extreme temperatures in summer and winter $\left(40^{\circ} \mathrm{C}\right.$ to $\left.-5^{\circ} \mathrm{C}\right)$, and thermic winter reversal. Vegetation (Braun-Blanquet \& De Bolós 1987) is naturally a steppe scrubland with scarce juniper trees (Juniperus thurifera). Surrounding the saline lakes is an evergreen halophytic vegetation.

Since the end of the nineteenth century the area has been converted into an extensive cereal plain (pseudosteppe) with extensive cereal crops of wheat (Triticum sp.) and barley (Hordeum sp.) (Suárez et al. 1992; J. Blasco, personal communication). These cereals are cultivated following traditional practices: sowing is carried out by plows in October and harvest is in June. The stubbles are exploited for extensive sheep grazing until the following winter (January-March) when fields are plowed (so plows remain uncultivated from March to October). The mean size of fields is about 15 ha, so margins between fields are numerous, consisting of accumulated stones and a natural vegetation similar to that of road edges. The area is one of the most representative Iberian pseudo-steppes (Suárez et al. 1992) and holds important populations of endangered steppary birds (Grimmett \& Jones 1989).

Between 1995 and 1996, important alterations affected around $40 \%$ of the study area. Fields got larger and larger, so a number of field margins began to disappear. This surface began to be irrigated in 1996 to allow for an intensive agricultural system similar to that of many of the Spanish plain areas. These changes are included in a project to irrigate $4748 \mathrm{~km}^{2}$ of pseudo-steppes of the Ebro Valley, substituting traditionally cultivated cereals with alfalfa, winter cereals, maize, sunflower, deciduous fruit trees, horticultural crops, and rice (Herrero \& Snyder 1997).

\section{Radiotracking Processes}

During 1994 nearly 300 pairs of Lesser Kestrels bred in 70 abandoned farm houses and other isolated buildings 
(Forero et al. 1996). Twenty-three breeding Lesser Kestrels (nine pairs, one male and four females) were radiotracked during the 1994 breeding season. Seven other birds (three males and four females) were also radiotracked but provided little information because of transmitter damage, brood failure, or other causes and were not considered in the analyses. Radio transmitters (Amaya SA, Mataró, Spain) were attached to the two central tail feathers so there would be no detrimental effect on the behavior, breeding success, or survival of birds (Hiraldo et al. 1994). Birds were tracked from 15 June to 18 July, the period of chick rearing when starvation risk is higher in populations suffering preferred habitat loss or food stress (Negro 1991). The birds were followed for $2-10$ days $(\bar{x}=4.4$ days; $12.6 \%$ of the rearing period [Bustamante \& Negro 1994]; Table 1). Four birds were followed every day by two research teams using cars. Two birds were tracked in the morning and the other two in the evening. Each team was supported by one person who monitored the nest, recorded data, and communicated by radio the prey deliveries to nestlings. Birds were followed closely for the same number of mornings and evenings to avoid possible shifts due to circadian rhythms of activity. For analytical purposes we excluded all observations when birds were not hunting (in the colony, directional flights). In our study areas Lesser Kestrels hunted mainly while hovering. Perch hunting and air hunting of flying insects were unusual.
We also excluded locations of birds perched on the ground because they were obviously resting. Moreover, we never observed a Lesser Kestrel capturing prey directly from a ground position.

Every time a bird was observed hunting, we recorded location and habitat use as follows: The study area was divided into cells of $500 \times 500 \mathrm{~m}$, derived from the $1 \times$ 1 squares on Universal Transverse Mercator (UTM) maps. We then plotted every location of the hunting birds within this area. We registered locations every 10 minutes (Negro et al. 1991). We classified habitats into the following seven categories: (1) cereals, (2) plowed fields, (3) abandoned fields (old uncultivated fields with short vegetation), (4) mediterranean scrubland, (5) field margins with rough grass vegetation, (6) halophytic vegetation surrounding the saline lakes, and (7) salt lakes (plain surfaces that are dry during the Lesser Kestrel's breeding season).

Mosaic landscapes such as those existing in the study area and flight hunting by the Lesser Kestrels would facilitate the existence of habitat-selection decisions at two spatial scales. First, coarse-habitat selection will occur when the bird is flight hunting; we noted the hunting time (minutes) spent by the bird making hunting flights in each habitat. Second, fine-habitat selection will take place when the bird captures the prey; we recorded the number of strikes made by the bird in each habitat. If environmental heterogeneity is high and habi-

Table 1. Tracking patterns of radio-tagged Lesser Kestrels.

\begin{tabular}{|c|c|c|c|c|c|c|c|c|c|}
\hline $\begin{array}{l}\text { Bird }^{a} \\
(\text { sex/code })\end{array}$ & $\begin{array}{c}\text { Colony } \\
\text { number }\end{array}$ & $\begin{array}{l}\text { Tracking } \\
\text { days }\end{array}$ & tracking & colony & displacements & ground & lost & bunting & babitat \\
\hline $\mathrm{m} / 7 \mathrm{H}$ & 18 & 4 & 677 & 117 & 41 & 151 & 226 & 368 & 354 \\
\hline $\mathrm{m} / 07$ & 5 & 4 & 611 & 104 & 33 & 0 & 328 & 474 & 393 \\
\hline f/OB & 5 & 4 & 528 & 70 & 39 & 51 & 380 & 368 & 273 \\
\hline $\mathrm{m} / 30$ & 50 & 5 & 723 & 49 & 141 & 81 & 498 & 452 & 360 \\
\hline f/E0 & 12 & 6 & 878 & 79 & 226 & 63 & 385 & 510 & 444 \\
\hline $\mathrm{m} / \mathrm{AV}$ & 8 & 4 & 682 & 118 & 117 & 35 & 260 & 412 & 325 \\
\hline f/CF & 8 & 6 & 798 & 138 & 163 & 29 & 508 & 468 & 305 \\
\hline f/US & 6 & 2 & 245 & 23 & 44 & 93 & 156 & 85 & 78 \\
\hline f/N6 & 35 & 10 & 764 & 192 & 185 & 0 & 877 & 387 & 288 \\
\hline $\mathrm{m} / \mathrm{K} 5$ & 16 & 2 & 372 & 71 & 113 & 0 & 146 & 188 & 172 \\
\hline f/L8 & 51 & 2 & 649 & 1 & 12 & 7 & 101 & 328 & 301 \\
\hline $\mathrm{m} / \mathrm{U} 4$ & 51 & 4 & 619 & 58 & 164 & 0 & 285 & 262 & 135 \\
\hline $\mathrm{f} / \mathrm{F} / \mathrm{E}$ & 51 & 7 & 774 & 63 & 108 & 5 & 813 & 387 & 211 \\
\hline $\mathrm{m} / 0 \mathrm{E}$ & 3 & 3 & 277 & 11 & 37 & 0 & 512 & 123 & 106 \\
\hline $\mathrm{f} / 79$ & 3 & 8 & 1598 & 71 & 412 & 71 & 629 & 590 & 454 \\
\hline f/OM & 3 & 6 & 449 & 126 & 87 & 0 & 602 & 166 & 70 \\
\hline
\end{tabular}

${ }^{a}$ Each bird identified by its band code and sex ( $m=$ males, $f=$ females).

${ }^{b}$ The number of minutes tracked (tracking, except those lost), the minutes observed in the colony (colony), making directional flights, perched on the ground, nonlocalized (lost), hunting, and bunting in habitats accurately determined (habitat). 
tat richness predictability is low, it can be foreseen that hunting kestrels will have noncoincident habitat selection patterns at the two spatial scales-birds could survey a determined habitat but make a final strike on a different one. On the contrary, habitat richness predictability would lead to strong similarities at the two scales.

When it was possible, hunting sequences of the marked individuals were also recorded, including the duration of the sequence (in seconds), the number of hovering bouts, and the number of prey captured. This information was analyzed only for those habitats that were most used by the kestrels because the number of locations in nonpreferred habitats was very low. To study the hunting yield of each type of habitat, we calculated three variables: (1) the number of seconds necessary to make a strike, (2) the number of hovering bouts required to make a strike, and (3) the number of strikes required to capture the prey. We also registered the prey sizes and divided them into three categories: invertebrates up to $3 \mathrm{~cm}$ long, invertebrates longer than $3 \mathrm{~cm}$, and vertebrates-mainly small mammals and lizards.

\section{Data Analysis}

Habitat availability for each focal bird was obtained within a $3-\mathrm{km}$ radius around its colony because about $95 \%$ of the hunting observations were within this distance. We used 1:50,000 maps of cultivation and landscape management edited by the Spanish Ministry of Agriculture to determine the surface occupied by mediterranean scrubland, halophytic vegetation, salt lakes, and crops. The proportion of these cultivation areas devoted to active crops (cereals) and plowed or abandoned fields during the study period was calculated based on 3-5 UTM squares $(1 \times 1 \mathrm{~km})$ that were randomly selected in the 3 $\mathrm{km}$ around the nest by means of 1:5000 agricultural maps and ground survey information. In the same $1 \times 1$ $\mathrm{km}$ squares we measured the surface occupied by field margins, using $0.95 \mathrm{~m}$ wide for margins separating fields and $3.4 \mathrm{~m}$ for margins separating fields from roads $(n=$ 104 random measurements).

To determine whether or not the habitats were randomly used by the Lesser Kestrels, we used compositional analysis (Aebischer \& Robertson 1992; Aebischer et al. 1993; Donázar et al. 1993). The main advantage of this method is the avoidance of biases due to the nonindependence of proportions in habitat use (Aebischer et al. 1993). We used log ratios of available, utilized habitat (area of influence of the colony: $y_{0}$; time spent by the bird in each habitat: $y$ ) and compositions using the proportion of cereal habitat as the denominator. We then calculated the difference, $d=y-y_{0}$. Taking the data matrix of $d$ values for each individual and habitat as a base, we calculated the relation $(L)$ between the determinant of the matrix of mean-corrected sums of squares and cross-products (hypothesis to be tested: differential habitat use) and the determinant of the matrix of raw sums of squares and cross products (null hypothesis: identical habitat use). The significance of $L$ was tested by means of the expression $-N l n L$, where $N$ is the number of Lesser Kestrels, which follows a chi-square distribution. To determine where the differences lie in habitat use and to order the habitats according to their use for every Lesser Kestrel, we constructed a table of the relative use of each habitat, calculating for each comparison between habitats the proportion in which it is used with respect to the available proportion (previously logtransformed). Finally, we compared the habitat preference in each habitat comparison with a random distribution provided by the computer program (Donázar et al. 1993).

Home ranges were determined for kestrels for which we obtained at least 20 hunting localizations. Because the number of locations for each bird and their home range sizes are not related $\left(r_{s}=0.019, p=0.934, n=\right.$ $22)$, we assumed that home-range size was not a function of sample size (White \& Garrot 1993). Thus, we were able to calculate the minimum perimeter polygon, which was the area enclosed when all localizations were joined to form a convex polygon (Mohr 1947). To quantify the intensity of use of the area, we used the harmonic mean method (Dixon \& Chapman 1980), considering $90 \%$ and $75 \%$ isopleths.

\section{Comparison with Intensively Cultivated Pseudo-Steppes}

We compared the results obtained in Los Monegros with those obtained in the Guadalquivir valley (Sevilla, southern Spain). This is also a pseudo-steppe area, but traditional cereal cultivation has been substituted for by intensive farming, which has caused the virtual disappearance of

Table 2. Potential hunting habitat availability (\%) in two regions with different agricultural systems: Monegros and the Guadalquivir valley.

\begin{tabular}{lccccc}
\hline & \multicolumn{2}{c}{$\begin{array}{c}\text { Monegros }^{a} \\
\left(11 \text { colonies }^{2}\right.\end{array}$} & & \multicolumn{2}{c}{$\begin{array}{c}\text { Gualdalquivir } \\
\text { (1 colony })\end{array}$} \\
\cline { 2 - 3 } \cline { 5 - 6 } & Mean & $S D$ & & 1989 & 1990 \\
\hline Grassland margins & 0.8 & $(0.1)$ & & 0.7 & 0.7 \\
Cereals & 41.0 & $(5.7)$ & 51.4 & 24.2 \\
Plowed fields & 41.0 & $(5.7)$ & - & - \\
Sunflowers & - & & 33.7 & 56.5 \\
Abandoned fields & 0.9 & $(0.1)$ & & - & - \\
Legumes & - & & & 1.2 & 2.4 \\
Melons & - & & 3.6 & 6.8 \\
Olive trees & - & & & 5.1 & 4.9 \\
Orange trees & - & & 4.0 & 3.9 \\
Scrubland & 13.6 & $(11.0)$ & - & - \\
Halophytic vegetation & 0.8 & $(0.7)$ & - & - \\
Salt lakes & 1.6 & $(1.6)$ & - & - \\
\hline
\end{tabular}

${ }^{a}$ Pseudo-steppe, traditionally cultivated.

${ }^{b}$ Pseudo-steppe under intense cultivation. 
natural vegetation (scrubland, halophytic zones) and the appearance of fruit trees and irrigated cultures (Table 2). Moreover, short-to-medium fallows disappeared and then uncultivated plows are not present during springsummer being substituted by crops other than cereals, such as sunflowers, that in some years even exceed the surface occupied by cereals (Table 2). In addition, fertil- izer and biocide treatments are more intensive than in the pseudo-steppes with traditional agro-grazing systems (Montaner et al. 1986).

Lesser Kestrels have been intensively monitored in the Guadalquivir area from 1988 onward (Hiraldo et al. 1996). Radio-tracking studies were carried out during 1989-1990 following the methodology of Donázar et al.

Table 3. Home range and habitat use patterns of the 23 radio-tracked Lesser Kestrels.

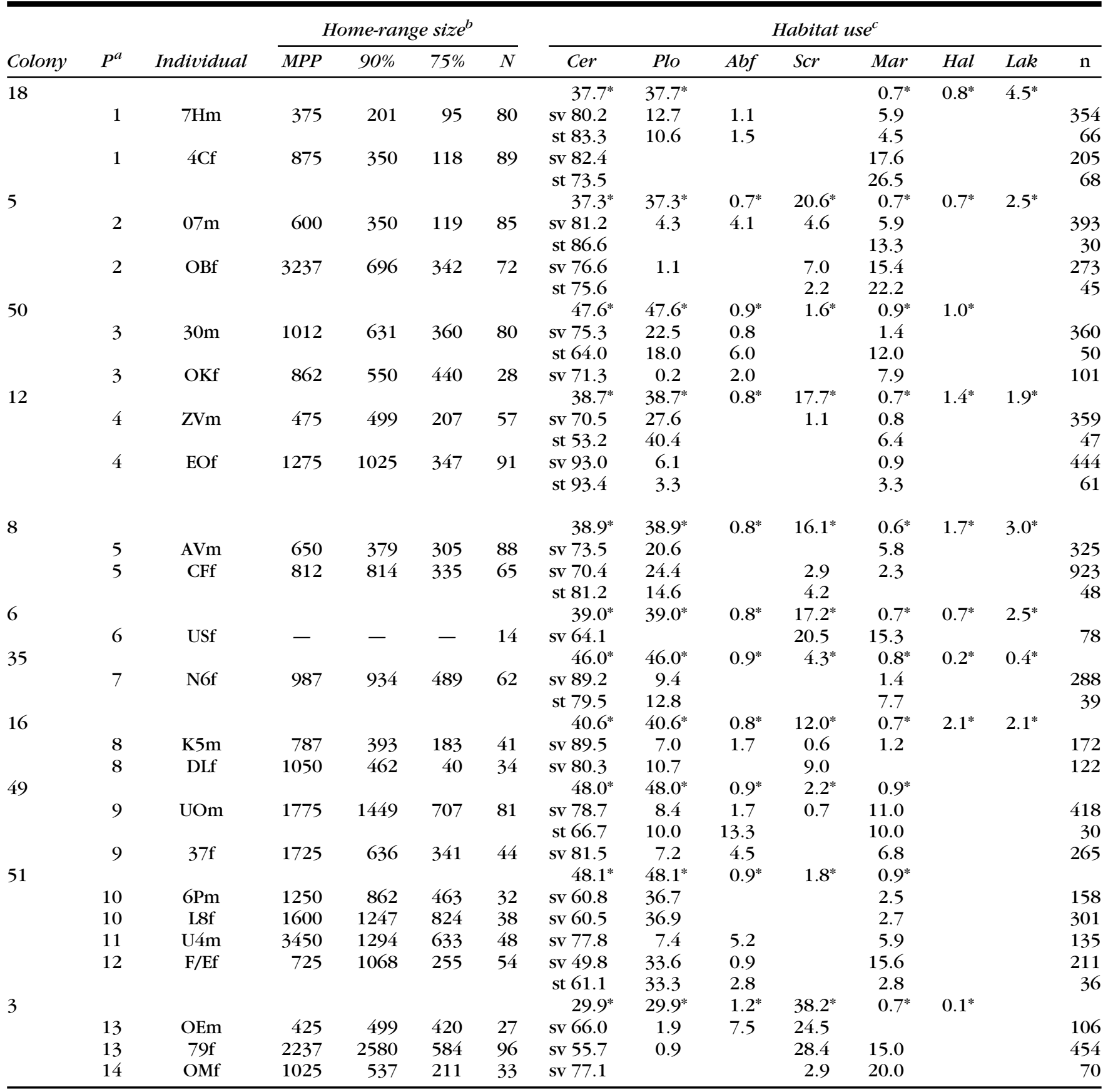

${ }^{a} P$ represents the pair with mates having the same number.

${ }^{b}$ For home-range data we show information (in ha) on minimum perimeter polygon (MPP) and harmonic means for $90 \%$ and $75 \%$ isopleths. $\mathrm{N}$ is the number of localizations.

${ }^{c}$ Data marked with an asterisk are the percentage of habitat surveyed (sv) and, if available, for habitat where the bird made strikes (st). $\mathrm{N}$ represents sample size for percentage calculations, minutes for habitat surveyed, and strikes for strike babitat. Cer, cereals; Plo, plowed fields; Abf, abandoned fields; Scr, scrubland; Mar, field margins; Hal, halophytic grassland; Lak, saline lake. 
(1993). We compared our data with Donázar et al.'s unpublished data from the chick-rearing period.

\section{Results}

\section{Pseudo-Steppes with Traditional Systems}

All the radio-tracked individuals tended to use similar hunting habitats (Table 3). The most-used habitat (100\% of the birds) was cereal, considering both coarse-habitat selection (habitat surveyed by hunting kestrels, $n=23$ birds) and fine-habitat selection (habitats where the kestrels made strikes, $n=11$ birds). Second, the birds used the plowed fields: $66.7 \%$ of the individuals for surveyed habitats and $63.6 \%$ for strike habitat. Less used were the field margins (6.3\% and $8.3 \%)$ and the scrubland $(4.0 \%$ and $0.6 \%)$. The saline areas were avoided $(0.1 \%$ and $0.0 \%$ for halophytic grassland and $0.0 \%$ for dry saline lakes).

The compositional analysis made for surveyed habitats gave a Wilk's lambda of $L=0.0840(p<0.001)$, so the birds did not use the habitats randomly. The calculation of the ranking matrix (Table 4 ) yielded the use of field margins $>$ cereals $>$ abandoned fields $>$ plowed fields $>$ halophytic grassland $>$ salt lakes $>$ scrubland. Field margins and cereals were used significantly more than any of the other habitats, but field margins were used more than cereals. The scrubland was used significantly less than the other habitats except saline lakes. The compositional analysis for the strike habitat gave a Wilk's lambda of $L=0.0638$ ( $p<0.001)$. The ranking matrix gave the same results as the former analysis (Table 4). Field margins and cereals were used to a similar degree and significantly more than the other habitats, and the scrubland less than the rest except saline lakes. Saline lakes were used less than abandoned fields.

The use of the preferred habitats showed important circadian variations (Fig. 1). The cereals were used homogeneously during the day but declined before sunset. Field margins and scrubland did not show any variation. The exploitation of plowed fields, however, showed a sharp maximum in the final hours of the day. In fact, the kestrels remained hunting in the plowed areas until sunset.

The number of seconds necessary to make a strike, considering each sequence as an observation, was the least in plowed areas $(\overline{\mathrm{x}}=96.1, \mathrm{SD}=68.3, n=9)$, followed by field margins $(\overline{\mathrm{x}}=136.1, \mathrm{SD}=170.3, n=18)$, and cereals $(\overline{\mathrm{x}}=151.9, \mathrm{SD}=149.4, n=21)$. The differences, however, were not significant (Kruskall-Wallis test, $z=2.74, p=0.25$ ). The number of hovering bouts to make a strike was similar among the used habitats: cereals, $\overline{\mathrm{x}}=4.8, \mathrm{SD}=2.2, n=22$; field margins, $\overline{\mathrm{x}}=5.5, \mathrm{SD}=$ 7.0, $n=16$; plowed fields, $\overline{\mathrm{x}}=5.8, \mathrm{SD}=4.6, n=9$ (Kruskall-Wallis test, $z=2.22, p=0.33$ ).

The number of prey obtained per strike was 0.74 in cereals ( $n=138$ strikes), 0.70 in plowed fields $(n=46)$, and 0.52 in field margins $(n=14)$, with no significant differences (chi-square $=5.225$, $\mathrm{df}=2, p=0.07$ ). The Lesser Kestrel captured mainly invertebrates less than 3 $\mathrm{cm}$ in length, followed by invertebrates greater than 3 $\mathrm{cm}$ long, and vertebrates (Fig. 2). The difference in prey size between the most-used habitats was significant (chisquare $=57.037, \mathrm{df}=4, p<0.0001$ ). The partitioning of the contingency table revealed that there was no significant difference between cereals and field margins. When these two habitats were considered together and compared to plowed fields, the proportion of large invertebrates $(>3 \mathrm{~cm})$ was significantly higher in cereals and margins $(p<0.01)$.

Table 4. Habitat ranking matrix for the radio-tagged Lesser Kestrels. ${ }^{a}$

\begin{tabular}{|c|c|c|c|c|c|c|c|c|}
\hline \multicolumn{9}{|l|}{ Habitats surveyed } \\
\hline Abandoned field & 0.424 & 0.000 & $2.488^{*}$ & $-4.042^{*}$ & 0.496 & 1.060 & $-2.695^{*}$ & 4 \\
\hline Scrubland & -2.063 & -2.488 & 0.000 & $-6.529 *$ & $-1.992^{*}$ & -1.427 & $-5.182^{*}$ & 0 \\
\hline Margin & 4.466 & 4.042 & 6.529 & 0.000 & $4.538^{*}$ & $5.102^{*}$ & $1.347^{*}$ & 6 \\
\hline Cereal & 3.119 & 2.695 & 5.182 & -1.347 & 3.190 & 3.755 & 0.000 & 5 \\
\hline \multicolumn{9}{|l|}{ Strike habitats ${ }^{b}$} \\
\hline Plowed field & 0.000 & -0.876 & $2.669^{*}$ & $-4.864^{*}$ & 0.577 & 0.873 & $-3.627^{*}$ & 3 \\
\hline Abandoned field & 0.876 & 0.000 & $3.545^{*}$ & $-3.988^{*}$ & 1.453 & $1.750^{*}$ & $-2.751^{*}$ & 4 \\
\hline Scrubland & -2.669 & -3.545 & 0.000 & $-7.533^{*}$ & $-2.092^{*}$ & -1.795 & $-6.269^{*}$ & 0 \\
\hline Margin & 4.864 & 3.988 & 7.533 & 0.000 & $5.440^{*}$ & $5.737^{*}$ & 1.237 & 6 \\
\hline
\end{tabular}

${ }^{a}$ Numbers marked with an asterisk $\left(^{*}\right)$ represent significant deviation from random at $\mathrm{p}<0.05$.

${ }^{b}$ Habitats where strikes were made. 


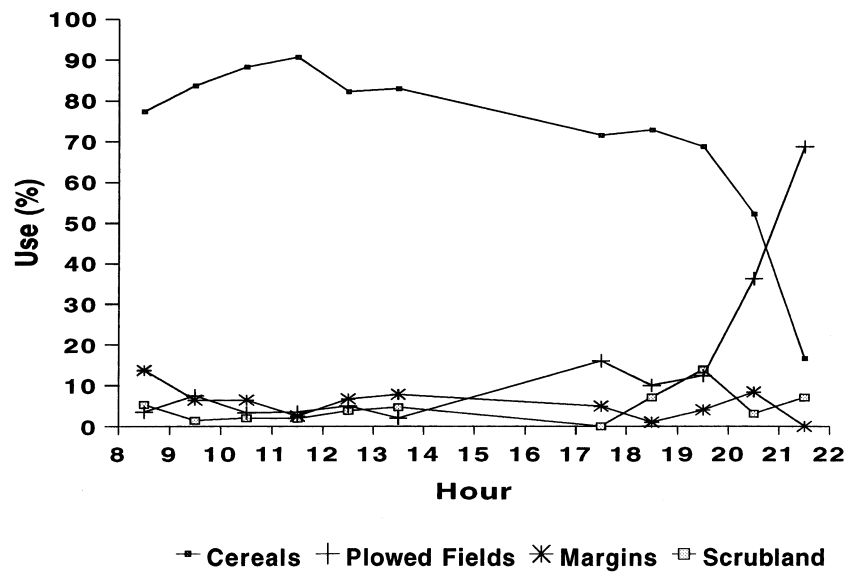

Figure 1. Distribution of bunting time througbout the day. In each of the babitats the percentage of time spent bunting (of the total time bunting in that babitat) is shown for every bour.

Home range was estimated for 22 Lesser Kestrels, showing a high individual variability (Table 3). Home ranges (MPP) averaged $12.36 \pm 8.28 \mathrm{~km}^{2}$, with males tending to have smaller home ranges than females $(\bar{x}=10.80$, $\mathrm{SD}=9.4, n=10$, versus $\overline{\mathrm{x}}=13.67, \mathrm{SD}=7.4, n=12$, respectively). In seven of the nine pairs that were tracked the females had larger home ranges for the three estimates (MPP, and contours of $90 \%$ and $75 \%$ isopleths); this tendency, however, was no different than that of a 1:1 proportion (binomial test, $p=0.227$, for the three variables).

\section{Comparison with Intensively Cultivated Pseudo-Steppes}

Following Donázar et al. (1993), in the intensively cultivated pseudo-steppes of the Guadalquivir valley, the pattern of habitat selection by the Lesser Kestrels was similar to that in Los Monegros. The sequence from the most- to the least-used habitat was as follows: field and river margins $>$ cereals $>$ legumes $>$ melons and vegetables $>$ olive trees $>$ sunflowers $>$ orange trees. The margins were used significantly more than the other habitats, except cereals; cereals more than olive and orange trees, and legumes more than orange trees.

The hunting yield of margins and cereals was similar in both of the agrosystems (Table 5); there were no significant differences in the number of seconds, the number of hovering bouts necessary for a strike, or the percentage of successful strikes. On the contrary, prey size was significantly larger in the pseudo-steppes with traditional agro-grazing systems in both cereals and field margins $(M \times N$ exact tests, $p<0.0001)$; the percentage of invertebrates greater than $3 \mathrm{~cm}$ was higher; and the capture of vertebrates was observed only in non-intensively cultivated pseudo-steppes (Fig. 2).

The home range size was significantly larger in the intensively cultivated pseudo-steppes (Table 5), whereas the percentage of $500 \times 500 \mathrm{~m}$ squares where kestrels got prey within the home range was significantly lower than in the traditionally cultivated areas.

\section{Discussion}

Birds of prey usually select as foraging habitats the more profitable areas based on the availability and/or accessibility of their main prey items (see review in Cody 1985). Lesser Kestrels prey mainly on invertebrates (Orthoptera and Coleoptera) and secondarily on small mammals and lizards (Tella et al. 1996a). In the traditionally cultivated pseudo-steppes, Lesser Kestrels preferred field margins with grass vegetation and cereals, for both finding and catching prey. Field margins and cereals showed a similar hunting yield, and we can expect that hunting yields in those habitats unused by Lesser

Table 5. Comparison of the results obtained in radio-tracking studies carried out in pseudo-steppes with traditional agro-grazing systems (TR P) (this paper) and pseudo-steppes intensively cultivated (IN P). ${ }^{a}$

\begin{tabular}{|c|c|c|c|c|c|c|c|c|}
\hline \multirow[b]{3}{*}{ System } & \multirow{2}{*}{\multicolumn{2}{|c|}{ Home range ${ }^{b}$}} & \multicolumn{3}{|c|}{ Field margins ${ }^{c}$} & \multicolumn{3}{|c|}{ Cereals $^{c}$} \\
\hline & & & \multicolumn{3}{|c|}{ Hunting performance } & \multicolumn{3}{|c|}{ Hunting performance } \\
\hline & $\operatorname{MPC}\left(\mathrm{km}^{2}\right)$ & used (\%) & $S / S$ & $H / S$ & prey $(\%)$ & $S / S$ & $H / S$ & prey (\%) \\
\hline \multirow{3}{*}{ TR P } & 12.36 & 55.87 & 136.1 & 5.5 & 0.50 & 151.9 & 4.8 & 0.73 \\
\hline & $(8.29)$ & $(24.86)$ & $(170.3)$ & $(7.0)$ & & $(149.9)$ & $(2.2)$ & \\
\hline & [22] & [22] & [18] & [16] & {$[22]$} & [21] & [22] & {$[138]$} \\
\hline \multirow{3}{*}{ IN P } & 63.65 & 8.99 & 140.6 & 4.3 & 0.42 & 123.3 & 4.3 & 0.66 \\
\hline & $(26.68)$ & $(3.37)$ & (61.8) & $(2.2)$ & & $(22.8)$ & (1.9) & \\
\hline & [4] & [4] & [17] & [17] & {$[103]$} & [7] & [7] & {$[61]$} \\
\hline$p$ & $0.0005^{d}$ & $0.0001^{d}$ & $0.181^{d}$ & $0.353^{d}$ & $0.637^{e}$ & $0.832^{e}$ & $0.524^{d}$ & $0.357^{e}$ \\
\hline
\end{tabular}

${ }^{a}$ Data based on reanalyzed data from Donázar et al. 1993. Standard deviations in parentbeses; sample sizes in brackets.

${ }^{b}$ Home-range size (MPC, in $\mathrm{km}^{2}$ ) and the percentage of $500 \times 500 \mathrm{~m}$ squares within the bome range used by the Lesser Kestrels (used).

${ }^{c}$ In each pseudo-steppe the preferred habitats were field margins and cereals; for these two babitats we show the bunting performance: $S / S=$ seconds to make a strike, $H / S=$ bovering bouts to make a strike, prey (\%) of strikes resulting in successful prey catching.

¿Mann-Whitney U test.

${ }^{e}$ Chi-square. 


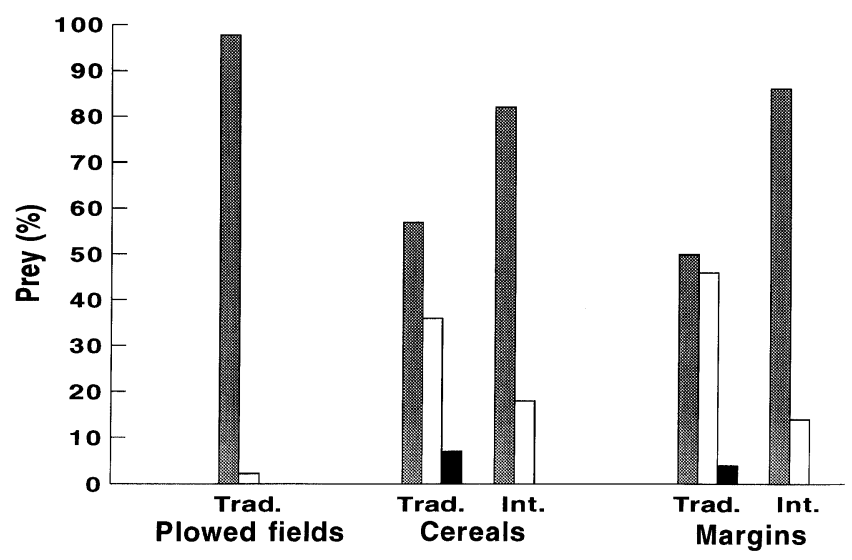

$\square$ Inv.<3 cm $\square$ Inv.>3 cm $\square$ Verteb.

Figure 2. Comparison of size of prey captured by Lesser Kestrels in the most-used habitats of the pseudo-steppe with traditional agro-grazing systems (Trad., $\mathrm{n}=282$ prey) and in the intensively cultivated system (Int., $\mathrm{n}=$ 353 prey). Plowed fields are not available in the second case.

Kestrels will be very low, as was confirmed in other radio-tracking studies on Lesser Kestrels (Donázar et al. 1993). This could be due to lower prey availability or to differences in the structure of vegetation among habitats determining prey accessibility (Shrubb 1980; Bechard 1982; Toland 1987). This seems unlikely, however, because differences in height and cover of vegetation among habitats are almost negligible in the study area (Tella et al. 1996b, personal observation). Cereals and field margins should therefore have higher availability of prey for the Lesser Kestrel (i.e., large invertebrates and small vertebrates). In cultivated areas, small mammals and lizards are confined largely to field margins with grass vegetation and refuge sites such as piles of stones (Gorman \& Reynolds 1993; Tew et al. 1994; personal observation). Large invertebrates such as orthoptera are also found more frequently in field margins of cultivated Mediterranean areas (Alonso \& Alonso 1990; Parr et al. 1997), and their abundance within cereal crops is higher near the borders of the field (personal observation).

In Los Monegros, Lesser Kestrels also used plowed fields and obtained hunting yields similar to those of cereals and field margins. Plowed fields were not actively selected, however, but used only at sunset to coincide with the circadian activity rhythms of an abundant Scarabeidae prey, Phylognathus excavatus. This beetle makes exclusive use of plowed fields during the adult stage, when it hides underground during the day and appears just before sunset ( $\mathrm{J}$. Blasco, personal communication). A similar circadian pattern of habitat selection was found for some nonpreferred habitats (legumes and melons) in other study areas (Donázar et al. 1993), where the larval stage of this beetle develops eating organic material. This fact reveals the importance of the traditional fallow systems, wherein stubbles are used for extensive sheep grazing and plowed several months later.

Lesser Kestrels selected similar habitats in both intensively and traditionally cultivated pseudo-steppes. Field and other grassland margins were selected first, after which cereal was the preferred habitat. These preferences are probably determined by their higher hunting yields, independent of the habitat's degree of transformation. But the size of captured prey is higher in pseudo-steppes with traditional agrosystems. Furthermore, the size of the Lesser Kestrel's home range is smaller in these areas than in the pseudo-steppes transformed by intensive cultivation, which clearly reveals a higher habitat quality, as has been noted for other species (Gargett 1975; Village 1982; Bloom et al. 1993). Foraging areas in intensively cultivated pseudo-steppes appear to be patchily distributed, forcing the Lesser Kestrels to prospect more extensive areas (Negro et al. $1993 b$ ) from which they catch prey in only about $9 \%$ of the total. In traditionally cultivated areas of Monegros, however, Lesser Kestrels use $56 \%$ of their home-range areas. The heterogeneity of habitat quality of intensive farming could be due to an increase in the use of biocides (Montaner et al. 1986; Nadal et al. 1996). Only untreated crops would maintain stable prey populations, whereas biocide treatments caused a sharp decline of prey availability in most of the areas (Hellmich 1991).

\section{Management Implications}

We show that the abandonment of field crops could have a negative effect on globally threatened steppe species such as the Lesser Kestrel because they avoid abandoned fields and mediterranean scrubland as foraging habitats. Also, the intensification of cultivation in pseudo-steppe areas has resulted in lower-quality foraging habitat for the Lesser Kestrel. Although the surface of preferred habitats has not changed, modern agricultural practices have determined the abandonment of traditional fallow systems; consequently, the hunting yield has decreased in terms of prey size as well as the homogeneity of habitat quality. Hence, the Lesser Kestrel has had to increase its home range and movement.

The effects of agricultural changes and intensification of cultivation seem to be determining the population trends of the Lesser Kestrel (Donázar et al. 1993). The productivity-number of fledglings per active nest-of colonies in intensively cultivated pseudo-steppes is lower due to an increase in nestling losses because of starvation (Negro 1991; Tella et al. 1996a). In these areas the populations have suffered a heavy decline (Hiraldo et al. 1996). In the traditional agro-grazed pseudo-steppe of Los Monegros the Lesser Kestrel population is increasing at a rate of $9-15 \%$ per year (Donázar et al. 1996) due to 
higher breeding success in spite of higher nestling and adult mortality rates caused by predation by wild carnivores (mainly red fox [Vulpes vulpes] and black rats [Rattus rattus]; Tella 1996; Tella et al. 1996a). Consequently, the more secure conservation status of traditionally cultivated pseudo-steppes allows the subsistance of Lesser Kestrel populations through higher food availability and, therefore, optimal breeding success.

The loss of preferred habitat and its lower quality as a result of the Common Agricultural Policy could have a similar effect on other threatened steppe birds. Although detailed studies of habitat selection for most of the other steppe birds are lacking, the available information suggests that most of them depend on traditionally farmed steppes (Suárez et al. 1997). Only some small threatened passerines (Dupont's Lark [Chersophilus duponti] and Spectacled Warbler [Sylvia conspicillata]) are associated with steppe shrubs, but in combination with livestock raising, for which protected areas of this vegetation are required. The extension of these protected steppe areas is not enough, because they do not generate social interest; in addition, economic conflicts arise between the agricultural sector and maintenance of uncultivated areas (Suárez et al. 1997). Under the recent Common Agricultural Policy pressures, however, it is a more urgent matter to design management systems compatible with nature conservation and centered on maintaining traditional farming methods, as has been proposed for other habitats or countries (Hopkins 1991; Bignal \& McCracken 1996). According to Bignal and McCracken (1996), future efforts from conservationists should address optimizing management practices in agricultural biotopes that are economically attractive to farmers. Since 1985 the CAP has progressively incorporated more-explicit environmental objectives. Article 19 of Regulation $797 / 85$, as amended by $1760 / 87$, allows for European Union members to provide assistance to environmentally sensitive forms of farming. The Agrienvironmental Regulation (EU Reg. 2078/92), can now be applied through zone programs, and it tends to favor economically those agricultural practices in keeping with wildlife conservation (Donázar et al. 1997). This help to farmers could be important in areas such as Los Monegros, where high soil salinity precludes a low agricultural income of intensive cultivars and land irrigation (Herrero \& Snyder 1997). This regulation could be a useful tool for setting concrete objectives such as those defined through this study: the maintenance of extensive agro-grazing cereal exploitations with inter-annual rotations, the maintenance of field sizes, an increase in the width of field margins, and the avoidance of treatments with biocides. Benefits could be extended to most of the threatened steppe species (especially bustards [Otis tarda and Tetrax tetrax], sandgrouses [Pterocles alchata and Pterocles orientalis], and Stone Curlew [Burbinus oedicnemus], and Chough [Pyrrhocorax pyrrbocorax] which are suffering from the transformation of traditional agro-grazed pseudo-steppes [Rodríguez \& De Juana 1991; Suárez et al. 1997, Blanco et al. 1998]), as well as to game species such as Red-legged Partridges (Alectoris rufa; Potts 1980; Rands 1986, 1987) that are of great economic and social interest.

\section{Acknowledgments}

This project was funded by the Dirección Natural de Medio Natural (Diputación General de Aragón) and project PB93-0040 of the Dirección General de Investigación Cientifica y Técnica. J.L.T. benefited from a predoctoral fellowship (Formación de Personal Investigador) of the M.E.C. We thank Y. Menor de Gaspar, O. Ceballos, R. López, and G. Blanco for assistance with the field work and J. J. Negro for comments on the manuscript. E. Collado made the computer programs required for the compositional analysis, E. Calleja supplied part of the cartography, and D. and N. Lawson helped with the English translation.

\section{Literature Cited}

Aebischer, N. J., and P. A. Robertson. 1992. Practical aspects of compositional analysis as applied to pheasant habitat utilization. Pages 285-293 in I. G. Priede and S. M. Swift, editors. Wildlife telemetry: remote monitoring and tracking of animals. Ellis Horwood, Chischester, United Kingdom.

Aebischer, N. J., P. A. Robertson, and R. E. Kenward. 1993. Compositional analysis of habitat use from animal radio-tracking data. Ecology 74:1313-1325.

Alonso, J., and J. A. Alonso. 1990. Parámetros demográficos, selección de hábitat y distribución de la avutarda (Otis tarda) en tres regiones españolas. Monografias del Instituto para la Conservación de la Naturalez, Serie Técnica, Madrid, Spain.

Baldock, D., and T. Long. 1987. The mediterranean environment under pressure: the influence of the CAP on Spain and Portugal and the "IMPs" in France, Greece and Italy. Institute for European Environmental Policy, Bonn.

Barceló, L. V., R. Compés, J. M. García, and C. Tió. 1995. Organización económica de la agricultura española. Adaptación de la agricultura española a la normativa de la UE. Fundación Alfonso Martín Escudero. Mundi-Prensa, Madrid.

Bechard, M. J. 1982. Effect of vegetative cover on foraging site selection by Swainson's Hawk. Condor 84:153-159.

Biber, J. P. 1994. Lesser Kestrel. Pages 188-189 in G. M. Tucker and M. F. Heath, editors. Birds in Europe: their conservation status. Birdlife Conservation Series Number 3. Birdlife International, Cambridge, United Kingdom.

Bignal, E. M., and D. I. McCracken. 1996. Low-intensity farming systems in the conservation of the countryside. Journal of Applied Ecology 33:413-424.

Blanco, G., J. L. Tella, and I. Torre. 1998. Traditional farming and key foraging habitats for Chough pyrrbocorax pyrrbocorax conservation in a Spanish pseudo-steppe landscape. Journal of Applied Ecology 35:in press.

Bloom, P. H., M. D. McCrary, and M. J. Gibson. 1993. Red-shouldered Hawk home-range and habitat use in southern California. Journal of Wildlife Management 57:258-265.

Braun-Blanquet, J., and O. De Bolós. 1987. Las comunidades vegetales 
de la depresión del Ebro y su dinamismo. Delegación de Medio Ambiente, Disputación Provincial de Zaragoza, Zaragoza, Spain.

Bustamante, J. 1997. Predictive models for Lesser Kestrel Falco naumanni distribution, abundance and extinction in southern Spain. Biological Conservation 80:153-160.

Bustamante, J., and J. J. Negro. 1994. The post-fledgling dependence period of the Lesser Kestrel (Falco naumanni) in southwestern Spain. Journal of Raptor Research 28:158-163.

Cody, M. 1985. Habitat selection in birds. Academic Press, London.

Colvin, B. A. 1985. Common Barn-owl population decline in Ohio and the relationship to agricultural trends. Journal of Field Ornithology 56:224-235.

Collar, N. J., M. J. Crosby, and A. J. Stattersfield. 1994. Birds to watch. 2. The world list of threatened birds. BirdLife International, Cambridge, United Kingdom.

Dixon, K. R., and J. A. Chapman. 1980. Harmonic mean measure of animal activity areas. Ecology 61:1040-1044.

Donázar, J. A., J. J. Negro, and F. Hiraldo. 1993. Foraging habitat selection, land-use changes and population decline in the Lesser Kestrel Falco naumanni. Journal of Applied Ecology 30:515-522.

Donázar, J. A., F. Hiraldo, J. L. Tella, and M. G. Forero. 1996. Establecimiento de las directrices de conservación del cernícalo primilla (Falco naumanni) en Monegros. Diputación General de Aragón, Zaragoza, Spain

Donázar, J. A., M. A. Naveso, J. L. Tella, and D. Campión. 1997. Extensive grazing and raptors in Spain. Pages 117-149 in D. Pain and M. W. Pienkowski, editors. Farming and birds in Europe. Academic Press, London.

Erichsen, A. L., S. K. Smallwood, A. M. Commandatore, B. W. Wilson, and D. Fry. 1996. White-tailed Kite movement and nesting patterns in an agricultural landscape. Pages $165-176$ in D. M. Bird, D. E. Varland, and J. J. Negro, editors. Raptors in human landscapes. Academic Press, London

Forero, M. G., J. L. Tella, J. A. Donázar, and F. Hiraldo. 1996. Can interspecific competition and nest site availability explain the decrease of Lesser Kestrel Falco naumanni populations? Biological Conservation 78:289-293.

Fuller, R. J., R. D. Gregory, D. W. Gibbons, J. H. Marchant, J. D. Wilson, S. R. Baillie, and N. Carter. 1995. Population declines and range contractions among lowland farmland birds in Britain. Conservation Biology 9:1425-1441.

Gargett, V. 1975. The spacing of black eagles in the Matopos, Rhodesia. Ostrich 46:1-44.

González, J. L., and M. Merino. 1990. El cernícalo primilla (Falco naumanni) en la Península Ibérica. Instituto para la Conservación de la Naturalez, Serie Técnica, Madrid, Spain.

Goriup, P. D., and L. Batten 1990. The conservation of steppic birds: a European perspective. Oryx 24:215-223.

Gorman, M. L., and P. Reynolds. 1993. The impact of land-use change on voles and raptors. Mammal Review 23:121-126.

Grimmett, R. F. A., and T. A. Jones. 1989. Important bird areas in Europe. International Council for Bird Preservation, Cambridge, United Kingdom.

Hellmich, J. 1991. La avutarda en extremadura. Monografía 2. Alytes, Mérida, Spain.

Herrero, J., and R. L. Snyder. 1997. Aridity and irrigation in Aragon, Spain. Journal of Arid Environments 35:535-547.

Hiraldo, F., J. J. Negro, and J. A. Donázar. 1994. Effects of tail-mounted radio transmitters on Lesser Kestrels. Journal of Field Ornithology 65:466-471

Hiraldo, F., J. J Negro, J. A. Donázar, and P. Gaona. 1996. A demographic model for a population of the endangered Lesser Kestrel in southern Spain. Journal of Applied Ecology 33:1085-1093.

Hopkins, J. J. 1991. Management of semi-natural lowland dry grasslands. Pages 119-124 in P. D. Goriup, L. A. Batten, and J. A. Norton, editors. The conservation of lowland dry grassland birds in Europe. Joint Nature Conservation Bureau Limited, Berkshire, United Kingdom.
Ministerio de Agricultura, Pesca y Alimentación. 1994. Programas de ayuda para fomentar métodos de producción agraria compatibles con las exigencias de protección y la conservación del espacio natural. Ministerio de Agricultura, Pesca y Alimentación, Madrid, Spain.

Mohr, C. O. 1947. Table of equivalent populations of North America small mammals. The American Midland Naturalist 37:223-249.

Montaner, J., F. Fourneau, J. Lleo, J. Paredes, G. Acosta, and R. Ceballos. 1986. Evolución de los paisajes y ordenación del territorio en Andalucía Occidental. Instituto del Territorio y Urbanismo, Madrid.

Nadal, J., J. Nadal, and J. D. Rodríguez-Teijeiro. 1996. Red-legged Partridge (Alectoris rufa) age and sex ratios in declining populations in Huesca (Spain) applied to management. Revue d'EcologieTerre et Vie 51:243-257.

Negro, J. J. 1991. Ecología de poblaciones del cernícalo primilla Falco naumanni. Ph.D. thesis. Universidad de Sevilla, Sevilla, Spain.

Negro, J. J., J. A. Donázar, F. Hiraldo, L. M. Hernández, and M. A. Fernández. 1993a. Organochlorine and heavy metal contamination in non-viable eggs and its relation to breeding success in a Spanish population of Lesser Kestrels. Environmental Pollution 82:201-205.

Negro, J. J., J. A. Donázar, and F. Hiraldo. 1993b. Home range of Lesser Kestrels (Falco naumanni) during the breeding season. Pages 144-150 in M. K. Nicholls and R. Clarke, editors. Biology and conservation of small falcons. Proceedings of a hawk and owl trust conference, Canterbury, United Kingdom, 1991. The Hawk and Owl Trust, London.

Newton, I. 1979. Population ecology of raptors. T. \& A. D. Poyser Ltd., Hertfordshire, England.

Pain, D., and J. Dixon. 1997. Why farming and birds in Europe? Pages 1-24 in D. Pain and M. W. Pienkowski, editors. Farming and birds in Europe. Academic Press, London.

Parr, S., P. Collin, S. Silk, J. Wilbraham, N. P. Williams, and M. Yarar. 1995. A baseline survey of Lesser Kestrels Falco naumanni in central Turkey. Biological Conservation 72:45-53.

Parr, S., M. A. Naveso, and M. Yarar. 1997. Habitat and potential prey surrounding Lesser Kestrel Falco naumanni colonies in central Turkey. Biological Conservation 79:309-312.

Potter, C. 1997. Europe's changing farmed landscapes. Pages 25-42 in D. Pain and M. W. Pienkowski, editors. Bird conservation and farming policy in the European Union. Academic Press, London.

Potts, G. R. 1980. The effects of modern agriculture, nest predation and game management on the population ecology of partridges, Perdix perdix and Alectoris rufa. Advances in Ecological Research 11:1-82.

Rands, M. R. W. 1986. The survival of gamebird chicks in relation to pesticide use of cereals. Ibis 128:57-64.

Rands, M. R. W. 1987. Hedgerow management for the conservation of partridges Perdix perdix and Alectoris rufa. Biological Conservation 40:127-139.

Robson, N. 1997. The evolution of the Common Agricultural Policy and the incorporation of environmental considerations. Pages 4378 in D. Pain and M. W. Pienkowsky, editors. Farming and birds in Europe. Academic Press, London.

Rodríguez, J. M., and E. De Juana. 1991. Land-use changes and the conservation of dry grassland birds in Spain. Pages 49-58 in P. D. Goriup, L. A. Batten, and J. A. Norton, editors. The conservation of lowland dry grassland birds in Europe. Joint Nature Conservation Bureau Limited, Berkshire, United Kingdom.

Schmutz, J. K. 1989. Hawk occupancy of disturbed grasslands in realtion to models of habitat selection. Condor 91:362-371.

Shrubb, M. 1980. Farming influences on the food and hunting of kestrels. Bird Study 29:109-115.

Smallwood, S. K., B. J. Nakamoto, and S. Geng. 1996. Association analysis of raptors on a farming landscape. Pages 177-190 in D. M. Bird, D. E. Varland, and J. J. Negro, editors. Raptors in human landscapes. Academic Press, London.

Stephens, D. W., and J. R. Krebs. 1986. Foraging theory. Princeton University Press, London. 
Suárez, F., H. Sáinz, T. Santos, and F. González. 1992. Las estepas ibéricas. Ministerio de Obras Públicas y Transportes, Madrid, Spain.

Suárez, F., M. A. Naveso, and E. De Juana. 1997. Farming in the drylands of Spain: birds of the pseudosteppes. Pages 297-330 in D. Pain and M. W. Pienkowsky, editors. Farming and birds in Europe. Academic Press, London.

Tella, J. L. 1996. Condicionantes ecológicos, costes y beneficios asociados a la colonialidad en el cernícalo primilla. Ph.D. thesis. University of Barcelona, Barcelona.

Tella, J. L., F. Hiraldo, J. A. Donázar, and J. J. Negro. 1996a. Costs and benefits of urban nesting in the Lesser Kestrel. Pages 53-60 in D. M. Bird, D. E. Varland, and J. J. Negro, editors. Raptors in human landscapes. Academic Press, London.

Tella, J. L., I. Torre, and C. Sánchez. 1996b. Habitat availability and roost-site selection by the Stone Curlew (Burbinus oedicnemus) in an arid cultivated landscape (Los Monegros, NE Spain). Revue d'Ecologie-Terre et Vie 51:153-159.

Tew, T. E., I. A. Tood, and D. W. McDonald. 1994. Field margins and small mammals. Pages 85-94 in N. Boatman, editor. Field margins: integrating agriculture and conservation. British Crop Protection Council, Farnham, United Kingdom.
Toland, B. R. 1987. The effect of vegetative cover on foraging strategies, hunting success and nesting distribution of American Kestrels in central Missouri. Journal of Raptor Research 21:14-20.

Tucker, G. M. 1991. The status of lowland dry grassland birds in Europe. Pages 37-48 in P. D. Goriup, L. A. Batten, and J. A. Norton, editors. The conservation of lowland dry grassland birds in Europe. Joint Nature Conservation Bureau Limited, Berkshire.

Tucker, G. M., and M. F. Heath. 1994. Birds in Europe: their conservation status. BirdLife International, Cambridge, United Kingdom.

van Dijk, G. 1991. The status of semi-natural grasslands in Europe. Pages 15-36 in P. D. Goriup, L. A. Batten, and J. A. Norton, editors. The conservation of lowland dry grassland birds in Europe. Joint Nature Conservation Bureau Limited, Berkshire, United Kingdom.

Village, A. 1982. The home range and density of kestrels in relation to vole abundance. Journal of Animal Ecology 51:69-80.

White, G. C., and R. A. Garrot. 1993. Analysis of wildlife radio-tracking data. Academic Press, San Diego.

Wilcove, D. S., C. H. McLellan, and A. P. Dobson. 1986. Habitat fragmentation in the temperate zone. Pages 237-256 in M. E. Soulé, editor. Conservation biology. Sinauer Associates, Sunderland, Massachusetts. 